\title{
PROMESAS DE LA TERAPIA GÉNICA OCULAR
}

\section{PROMISE OF OCULAR GENE THERAPY}

\author{
URTTI A $^{1}$
}

El principio de la terapia génica es sencillo: la secuencia génica terapéutica se clona en un sistema de expresión que es un ADN plasmídico no viral o un vector viral. Una vez introducido en las células destinatarias, el sistema de expresión desencadena la producción de la proteína codificada por el transgén. En principio, es posible expresar cualquier proteína mediante transferencia génica a las células destinatarias. En la era posgenómica cada vez disponemos de más información sobre el papel de diversos genes y sus proteínas asociadas en la regulación de las funciones de células sanas y enfermas. Esta información le proporciona a la comunidad científica los genes para la terapia génica. Es importante señalar que dicha terapia no se limita al tratamiento de enfermedades hereditarias, y su propósito no es corregir defectos génicos en el genoma. Lo que hace la transferencia génica es guiar a las células hacia la producción de la proteína que le falta al tejido enfermo.

Existen diversas modalidades de terapia génica. Según el método de transferencia génica, pueden dividirse en terapias mediadas por vectores virales y terapias no virales con nanopartículas. Por otro lado, la terapia génica puede transducir material génico a las células con el objetivo de que produzcan la proteína terapéutica para sí mismas o bien la secreten al tejido y las células circundantes, a semejanza de un sistema de liberación controlada de fármaco. También es posible transfectar las células fuera del organismo y trasplantarlas luego en el contexto de una terapia celular o un trasplante quirúrgico.

La introducción de genes por medio de virus es la forma más frecuente de administrar genes a las células destinatarias. La primera generación de vectores se basaba en adenovirus, pero su seguridad dejaba que desear, por lo que en la actualidad se están estudiando otros vectores. En particular, los vectores génicos basados en virus adenoasociados (AAV-2) gozan ya de gran aceptación entre la comunidad investigadora. El AAV introduce eficazmente el gen en las células retinianas y la duración del efecto tras una sola inyección llega incluso a un año. Por lo tanto, no es necesario realizar administraciones frecuentes. Hasta el momento, tanto la seguridad de los vectores AAV-2 como la eficacia de su transferencia génica parecen satisfactorias. Se ha constatado el restablecimiento de la función retiniana, e incluso de la visión, en estudios en animales, y muy recientemente también en seres humanos. En un pequeño grupo de pacientes con degeneración retiniana y pérdida de visión, ésta mejoró o se mantuvo sin cambios en dos estudios independientes. Este es el primer informe que demuestra una mejoría clínica de la visión en la degeneración retiniana (1).

También se han empleado nanopartículas para la transferencia génica en el ojo. Sin embargo, pese a que se han obtenido algunos resultados positivos, dicha transferencia es poco eficaz in vivo. Parece que las células del epitelio pigmentario de la retina (EPR) son más fáciles de transfectar que las de la retina neurosensorial. La transfección de células del EPR está limitada por las barreras del humor vítreo y de la retina neurosensorial, pero si es posible transfectar células diferenciadas del EPR, secretarán el producto del transgén durante un largo periodo de dos meses $(2,3)$. Es interesante el hecho de que, al parecer, el factor clave no es la mayor o menor cantidad de ADN introducida en el núcleo, sino la actividad del transgén dentro de éste. La transfección de células del EPR es una opción interesante porque, una vez transfectada con los genes adecuados, esta capa celular podría secretar factores neurotróficos dirigidos a la retina neurosensorial o bien factores angiostáticos destinados a la coroides.

La terapia celular es una opción muy atractiva para el tratamiento de afecciones oculares. Puede llevarse a cabo una transfección estable de las célu-

\footnotetext{
${ }^{1}$ Centre for Drug Research. University of Helsinki. Finland. Arto.urtti@helsinki.fi
} 
las para que secreten la proteína de manera permanente. La línea de células del EPR llamada ARPE19 parece adecuada para la microencapsulación prolongada. Presumiblemente, estas células pueden mantenerse viables durante largos periodos porque no necesitan multiplicarse (4). Es esencial que las microcápsulas tengan paredes lo bastante permeables como para evitar que la proteína secretada, pero aún no liberada, se acumule en su interior. Se ha utilizado recientemente la tecnología de encapsulación celular en ojos para lograr la secreción de factor neurotrófico ciliar (CNTF) en el vítreo (5). El cilindro se implanta quirúrgicamente a través de la pars plana. Los resultados del ensayo clínico fueron prometedores: se observó mejoría de la visión en muchos pacientes con degeneración retiniana.

Las perspectivas de la terapia génica ocular son muy prometedoras. Se han obtenido los primeros resultados clínicos positivos y están surgiendo varias tecnologías nuevas, como los ARN interferentes pequeños (ARNip) y los microARN (miARN) para el silenciamiento génico, los oligonucleótidos llamados antagomires (antagonistas de los miARN) para anular dicho silenciamiento, las células pluripotentes inducidas y su modificación genética, y las técnicas para dirigir los genes a lugares específicos del genoma. Es interesante señalar que algunos fármacos basados en el silenciamiento génico mediante ARNip (para el tratamiento de la degeneración macular asociada a la edad) son ya objeto de ensayos clínicos de fase III. No cabe duda de que, en el ámbito de la terapéutica ocular, el desarrollo de novedosas terapias génicas y de medicamentos basados en genes avanza a buen ritmo.

\section{BIBLIOGRAFÍA}

1. Bainbridge JW, Smith AJ, Barker SS, Robbie S, Henderson $R$, Balaggan K, et al. Effect of gene therapy on visual function in Leber's congenital amaurosis. N Engl J Med 2008; 358: 2231-2239.

2. Pitkänen L, Ruponen M, Nieminen J, Urtti A. Vitreous is a barrier in non-viral gene transfer by cationic lipids and polymers. Pharm Res 2003; 20: 576-583.

3. Mannermaa E, Rönkkö S, Urtti A. Non-invasive kinetic analysis of transgene expression in differentiated cultured retinal pigment epithelial cells. Curr Eye Res 2005; 30: 345-353.

4. Wikström J, Elomaa M, Syväjärvi H, Kuokkanen J, Yliperttula M, Honkakoski P, et al. Alginate Based Microencapsulation of Retinal Pigment Epithelial Cell Line for Cell Therapy. Biomaterials 2008; 29: 869-876.

5. Sieving PA, Caruso RC, Tao W, Coleman HR, Thompson DJ, Fullmer KR, et al. Ciliary neurotrophic factor (CNTF) for human retinal degeneration: phase I trial of CNTF delivered by encapsulated cell intraocular implants. Proc Natl Acad Sci USA 2006; 103: 3896-3901. 